Thorax (1946) 1, 118.

\title{
THE EXAMINATION OF THE SPUTUM AND PLEURAL FLUID IN THE DIAGNOSIS OF MALIGNANT DISEASE OF THE LUNG
}

BY

\section{J. BAMFORTH}

\section{St. Thomas's Hospital, London}

Prior to 1935, when Dudgeon and Wrigley published their paper on the demonstration of particles of malignant growth in the sputum by means of the wet film method, the finding of malignant cells in sputum was a rare and fortuitous occurrence. In exceptional cases quite large fragments of tissue, visible to the naked eye, are coughed up, and from these sections can be prepared for histological examination and a diagnosis of malignancy made. Apart from cases of this type the demonstration of malignant cells in sputum had not been attempted. Dudgeon and Wrigley, however, showed that the systematic examination of specimens of sputa from suspected cases of malignant disease of the lung could yield a large percentage of positive results. Out of 58 cases investigated 38 ultimately proved to be malignant, and of the latter 26 , or 68 per cent, were diagnosed by examination of the sputum. Among the remaining cases which proved to be non-malignant one false positive result was obtained. In a later paper Dudgeon (1936) reported that the total number of cases examined in the Louis Jenner Laboratory, St. Thomas's Hospital, had risen to 102, and of these 56 were eventually found to be proved cases of malignant disease of lung or larynx. Out of the 56, a total of 43 , or 76 per cent, were diagnosed by examination of sputum. There were now two cases in which particles of malignant growth were stated to be present in the sputum and which proved to be of inflammatory nature.

TABLE I

BARRETT (1934-DECEMBER 1，1937)

\begin{tabular}{|c|c|c|c|}
\hline & & $\begin{array}{l}\text { Number of cases in which the } \\
\text { sputum diagnosis was con- } \\
\text { firmed by sections made from } \\
\text { post-mortem material }\end{array}$ & $\begin{array}{l}\text { Number of cases in which the } \\
\text { sputum diagnosis was con- } \\
\text { firmed by sections made from } \\
\text { material removed at broncho- } \\
\text { scopy or from sections of glands }\end{array}$ \\
\hline $\begin{array}{l}\text { Oat cell carcinoma } \\
\text { Columnar cell carcinoma } \\
\text { Squamous cell carcinoma }\end{array}$ & $\begin{array}{l}55 \\
37 \\
18\end{array}$ & $\begin{array}{r}19 \\
12 \\
6\end{array}$ & $\begin{array}{r}11 \\
15 \\
5\end{array}$ \\
\hline Secondary carcinoma & 9 & & \\
\hline
\end{tabular}


In December 1938 Barrett summarized the results obtained at St. Thomas's Hospital from the time that Dudgeon and Wrigley first introduced this method of examination until the end of November 1937. The total number of positive cases obtained during this period was 119 . These results, giving the relative frequency with which different types of malignant growth were found in the sputum, are shown in Table I.

The total number of cases investigated from which these positive results were obtained is not given because the requests for these examinations were increasing considerably. The examination of sputum for malignant cells had become almost a routine procedure.

The examination of sputum for malignant cells by this technique has been carried on since December, 1937. Owing to the war the work has suffered from repeated interruptions and periods of considerable difficulty, and it has proved impossible in many cases to follow up the after-history. There are, however, a further 113 positive results to report. These cases are classified in Table II.

TABLE II

Positive Results for Malignant Disease from Sputum Examination December 1, 1937, to MARCH 31, 1946

\begin{tabular}{l|c|c|c|c|c}
\hline & & $\begin{array}{c}\text { Oat } \\
\text { cell } \\
\text { carcinoma }\end{array}$ & $\begin{array}{c}\text { Columnar } \\
\text { cell } \\
\text { carcinoma }\end{array}$ & $\begin{array}{c}\text { Squamous } \\
\text { cell } \\
\text { carcinoma }\end{array}$ & $\begin{array}{c}\text { Secondary } \\
\text { carcinoma }\end{array}$ \\
\hline $\begin{array}{l}\text { Confirmed by post mortem; biopsy of } \\
\text { gland or tissue from bronchoscopy }\end{array}$ & 33 & 17 & 7 & 9 & - \\
$\begin{array}{l}\text { Died shortly afterwards; but no post- } \\
\text { mortem examination }\end{array}$ & 28 & 15 & 7 & 4 & 2 \\
\begin{tabular}{l} 
No further information obtained \\
\hline Total
\end{tabular} & 52 & 26 & 19 & 6 & 1 \\
\hline
\end{tabular}

\section{Examination of Pleural Fluid}

During this period (December 1, 1937, to March 31, 1946) a number of specimens of pleural fluid were also examined. In four of the cases shown in Table II malignant cells were found in the pleural fluid as well as in the sputum. In one typical case oat cells were found in the sputum, and columnar cells in the pleural fluid. In twenty-six cases a positive diagnosis was made by examination of the pleural fluid only, and these results are shown in Table III.

In the thirteen cases considered to be primary carcinomata of the lung no evidence of neoplasm was found outside the chest. In these, columnar cells were found in the pleural fluid of twelve; oat cells only in one case. In sections prepared from lung tissue obtained from post-mortem examination of three of these cases, little groups of columnar cells can be seen lying just beneath the endothelium of the pleura. Oat cells were rarely found in the pleural fluid, and 
TABLE III

Positive Results for Malignant Disease from Examination of Pleural fluid only (Sputum Negative or not Available) December 1, 1937, to MarCh 31,, 1946

\begin{tabular}{l|c|c|c}
\hline & Primary & Secondary & Total \\
\cline { 2 - 3 } Confirmed by post-mortem examination & 3 & 3 & 6 \\
Died shortly afterwards, but no post-mortem examination & 3 & 6 & 9 \\
No further information & 7 & 4 & 11 \\
\hline
\end{tabular}

so far squamous cells from cases of primary squamous cell carcinoma have not been found.

Fragments of secondary carcinoma would appear to be not infrequently found in pleural fluid. Seven cases showed fragments of spheroidal cell carcinoma in the pleural fluid secondary to primary carcinoma of the breast. In these there was a history of radical operation for removal of the breast at some previous date, recent or remote. The clumps of spheroidal cell carcinoma were unmistakable, and could not be confused with endothelial or other cells occurring in pleural fluid. In two cases these clumps showed a curious and distinctive appearance. They occurred as tiny spheres enclosed by a covering of endothelial cells obviously detached from the pleura. A post-mortem examination on one of these two cases showed a widespread papillomatous growth over both parietal and visceral pleura. There was considerable variation in the size of the papillomata and detachment of the smaller ones could produce this curious finding in the pleural effusion (Fig. 5).

In four cases there was conclusive evidence of primary growth of the ovary, and clumps of columnar cells were found in the pleural fluid. Confirmation was obtained in one of these by post-mortem examination.

In two cases there was a history of previous operation for carcinoma of the cervix uteri, and fragments of squamous cells were found in the pleural fluid. Cell nests were not observed in either case. A post-mortem examination in one showed that the carcinoma had spread upwards to the chest by the lymphatics, malignant glands being found along the abdominal aorta, in the posterior mediastinum, and above the left clavicle.

We have received information that two false positive results of sputum examination have been reported. In each of these cases the pulmonary lesion proved to be of inflammatory origin. To the second of these mistakes reference will be made later.

\section{Oat Cell Carcinoma}

As is shown in Table III, fragments of oat cell carcinoma are more frequently found in the sputum than are those of any other variety. In our experience oat cell carcinoma presents less difficulty in diagnosis than do other varieties of malignant disease. As compared with the columnar and squamous cell types the 


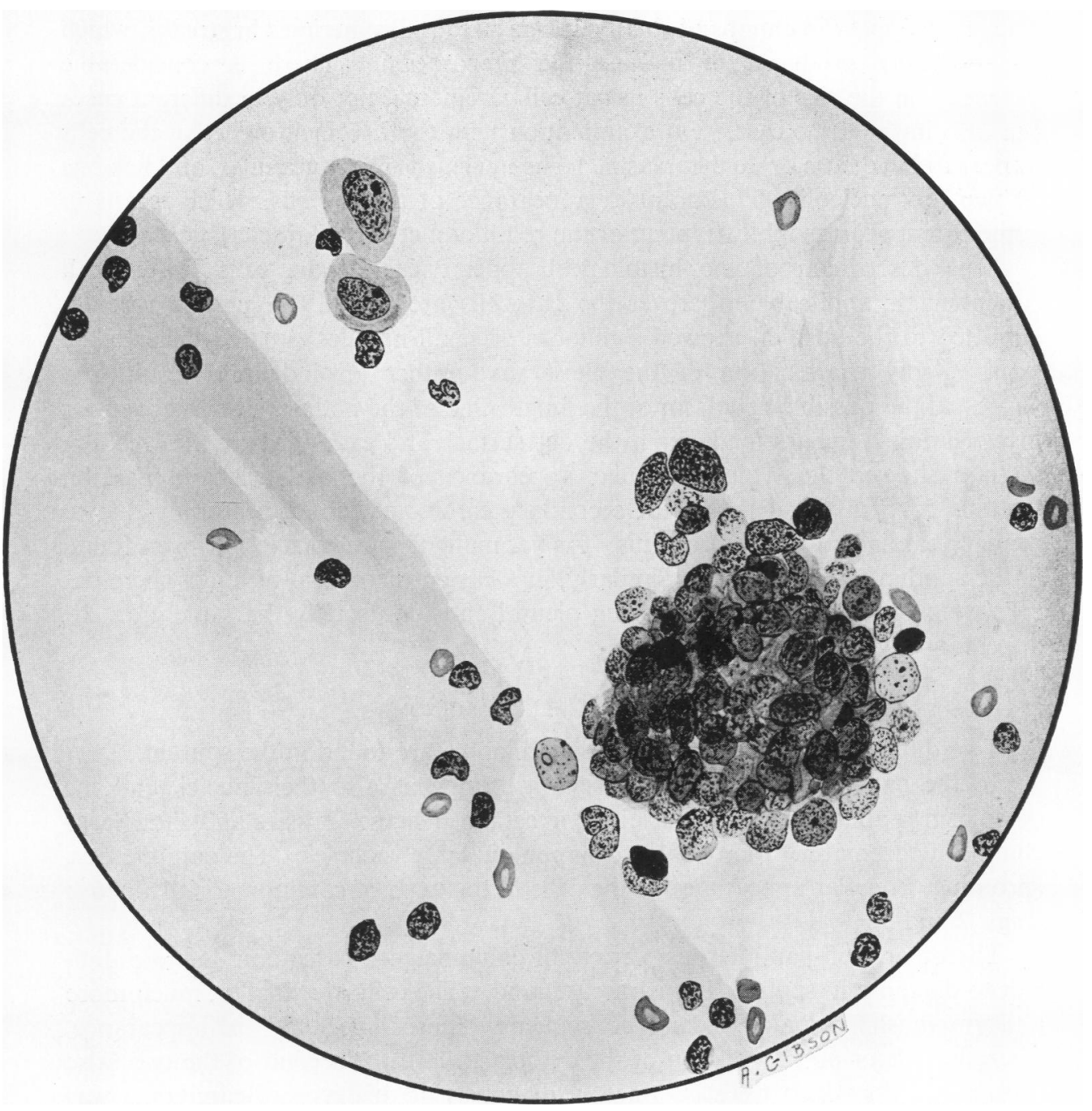

Fig. 1.- Showing a large fragment of oat cell carcinoma in pleural fluid. Two endothelial cells from the pleura are seen in the upper part of the picture. The diagnosis was confirmed at autopsy. 
fragments of oat cell carcinoma are, as a rule, much more abundant. Under the low power of the microscope the clusters of oat cell carcinoma stand out sharply. They may appear in clumps of small or large size, and sometimes in streaks, which are probably produced in making the preparation. There is considerable difference in the size of the cells in oat cell carcinoma, not only in different cases but also in the same case. On examination with the $1 / 6$ inch objective the cells appear to have little or no cytoplasm. The nucleus is finely granular, and has one or two tiny nucleoli. This granular appearance of the nucleus, which recalls to some extent the basophil stippling of the red blood cell, is characteristic.

This description of the histological appearances of the cells in oat cell carcinoma is applicable wherever the oat cells are found. A patient recently admitted to the hospital showed a number of small nodules situated beneath the skin. X-ray examination of the chest gave rather an indefinite result, but suggested the possible neoplasm of the lung. One of the nodules was removed for investigation. Smears made from the cut surface and examined by the wet film method showed the typical granular appearance of the oat cells and paraffin sections confirm the diagnosis of secondary carcinoma, almost certainly due to primary carcinoma of the bronchus. As yet malignant cells have not been found in the sputum of this patient. Similarly, in a case of neoplasm of lung, where oat cells were found in an accompanying pleural effusion, exactly the same granular appearance was shown (Fig. 1).

\section{Columnar Cell Carcinoma}

Two different types of columnar cell carcinoma are found in the sputum.

In the papilliferous variety the cells are large as also their nuclei, and the cytoplasm is abundant. The nuclei are irregular in shape and size and show large clumps of chromatin. Many of the cells contain large vacuoles. The papilliferous, sprouting, irregular appearance of the cells in this type of carcinoma is distinctive (Figs. 2 and 3).

The other, non-papilliferous, variety of columnar cell carcinoma is more difficult to diagnose in sputum, but is rarely found. The cells are smaller, much more uniform in shape and size, and consequently more "normal" in appearance. There is little or no vacuolation of the cytoplasm. In the second of the two false positive results which were obtained, a diagnosis of this type of carcinoma was made. The patient had a severe recurring haemorrhage from the lung and a lobectomy was done. Through the kindness of Dr. J. W. Clegg we had the opportunity of examining the specimen. A large bronchiectatic cavity about the size of a walnut was present. At one point of the wall, which showed marked chronic inflammatory changes, was a small papillomatous process over which the covering epithelium was absent. The process was formed of a vascular granulation tissue containing many plasma cells and capillaries, and was undoubtedly the site of haemorrhage. On either side of it, and extending for a considerable distance over the wall of the bronchiectatic cavity, an extensive change had taken place in the 


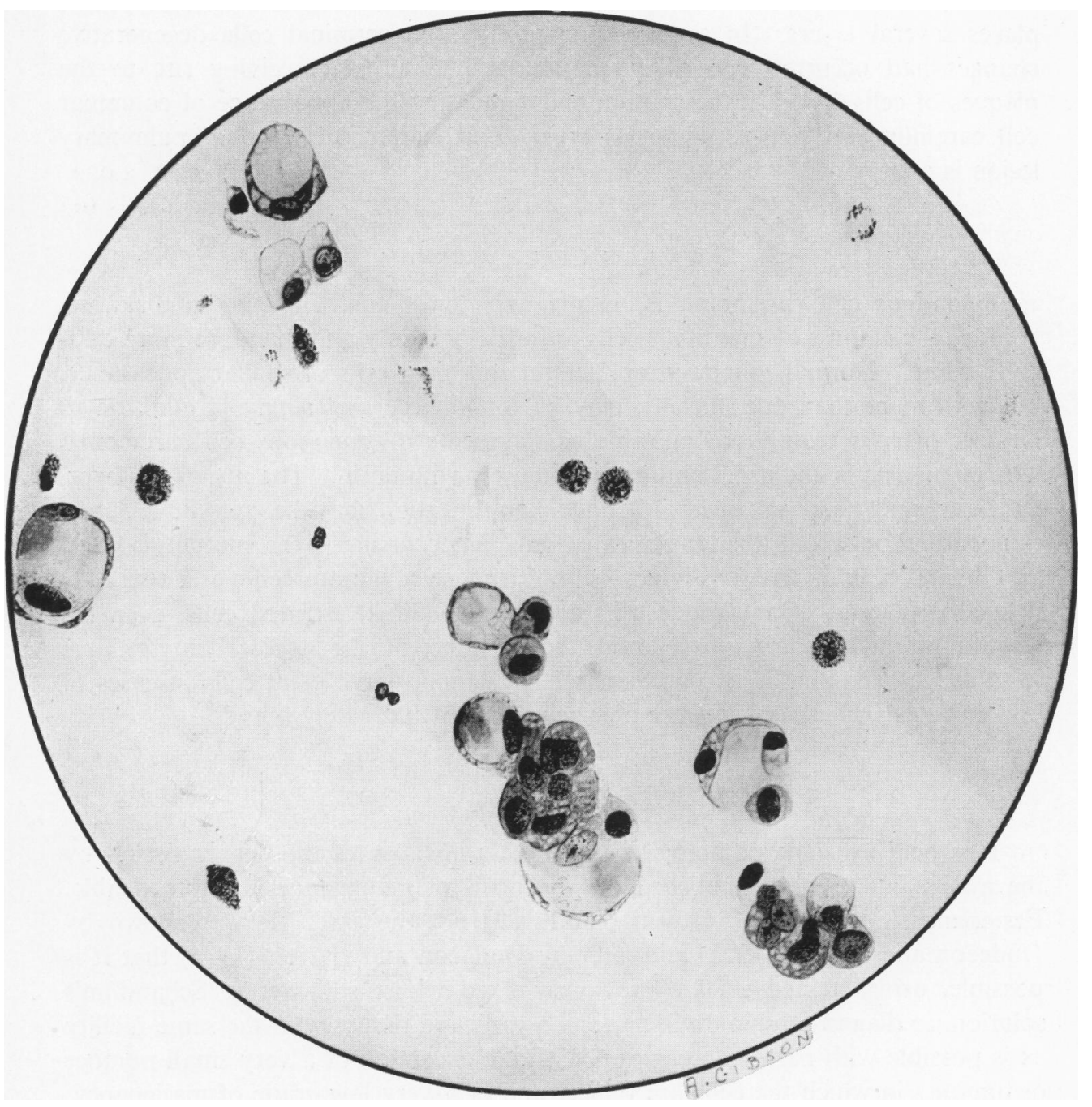

FIG. 2.-Showing clumps of papilliferous columnar cell carcinoma in the sputum, also some eosinophil cells. Some malignant cells are vacuolated. Diagnosis confirmed at autopsy. 
epithelial lining. The superficial columnar cells normally present had disappeared and there was a considerable hyperplasia of the germinal cells forming in some places several layers. In some of the proliferated germinal cells degenerative changes had occurred and desquamation had taken place, giving rise to the plaques of cells found in the sputum and simulating the appearance of columnar cell carcinoma of non-papilliferous type. Fortunately this type of pulmonary lesion is of rare occurrence.

\section{Squamous Cell Carcinoma}

Squamous cell carcinoma is, in my experience, also difficult to diagnose, because the clumps of squamous cells are usually scanty and therefore more difficult to find. Normal squamous epithelium and giant cells of similar appearance, but with more than one nucleus, may be found occurring singly in addition to clusters of cells readily recognizable as fragments of squamous cell carcinoma. The cytoplasm is abnormal and stains intensely with eosin. The nuclei are large, irregular, and deeply stained. Definite keratinization may be present (Fig. 4). A good description of this type of carcinoma, as occurring in the sputum, is given by Gloyne. I think that it is important to diagnose squamous cell carcinoma only if typical plaques of squamous cells are found. Single isolated cells, even the large multinucleated giant cells in the absence of the typical clumps, are insufficient. On one or two occasions I have found large giant cells in cases of bronchiectasis where no evidence of carcinoma was ultimately found.

\section{Conclusions}

It is held by some pathologists that unless invasion of the deeper tissues by the malignant cells is established the diagnosis of malignancy is impracticable. Experience, however, has proved that this is not the case. It was shown by Dudgeon and Patrick (1927) and later by Dudgeon and Barrett (1934) that it is possible, using stained smears previously fixed whilst still wet in Schaudinn's solution, to diagnose tumours of various organs and tissues with the same facility as is possible with paraffin sections. With the exception of a very small number of tumours in which the cells are typical and of a very low grade of malignancy, it is known that there are certain characteristics of malignant cells which differentiate them from benign cells. The malignant cells show considerable variation in shape and size, an increased staining of nucleus and cytoplasm, and a tendency to form syncytial masses and to undergo certain degenerative changes.

In the examination of the sputum for malignant cells it is better, if possible, to have a fresh specimen. In the case of pleural fluid this is essential. It is not proposed in this paper to give a detailed description of the technique of fixation and staining. Reference should be made to the papers of Dudgeon and Wrigley and of Barrett. For staining the preparations we have always used Mayer's 


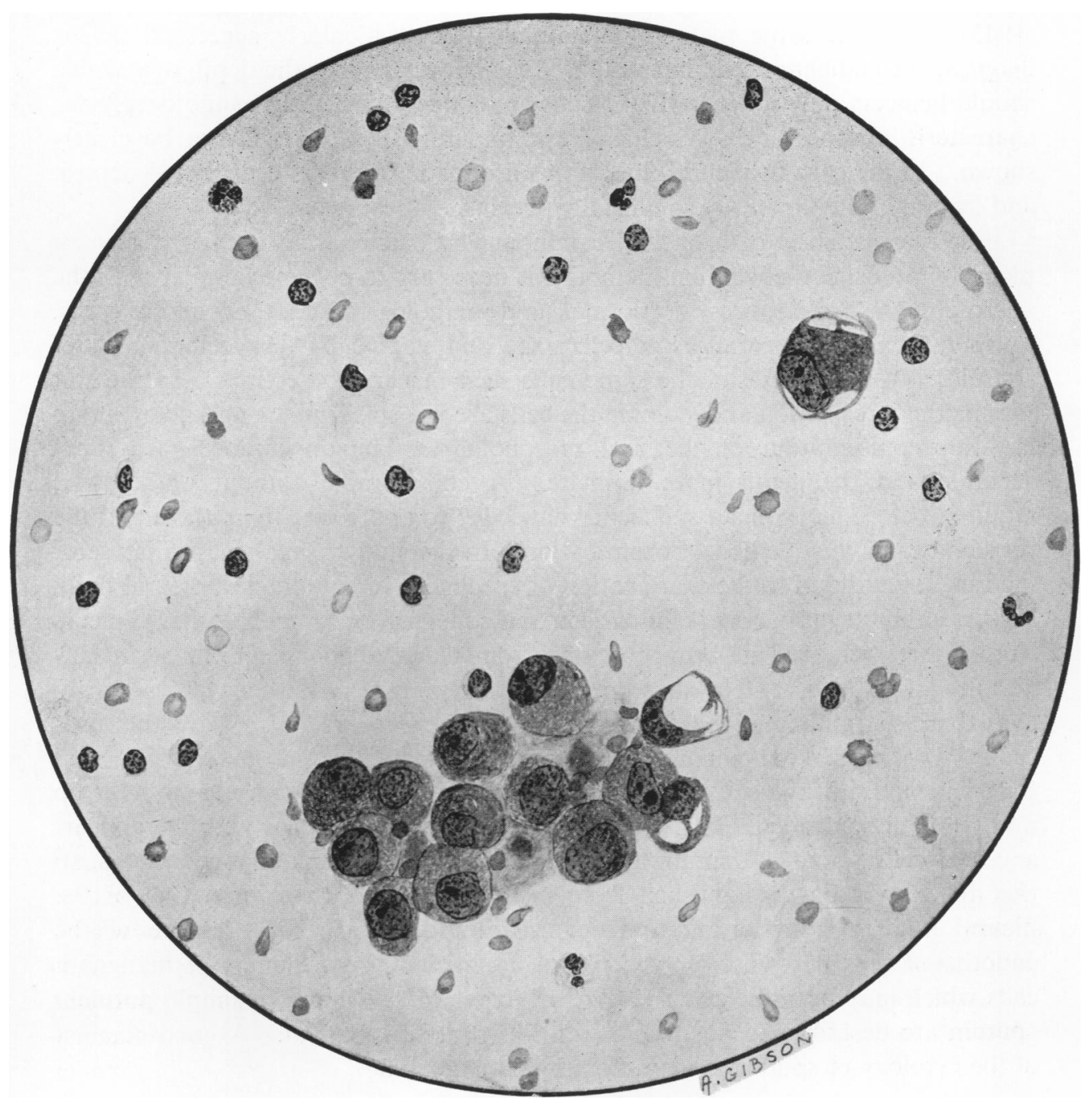

FIG. 3.-A clump of columnar cell carcinoma found in the pleural fluid from a case of primary carcinoma of lung. Diagnosis confirmed at autopsy. 
haemalum and eosin as originally described, and although on a few occasions other stains have been employed also, we have not found them so good. Gowar (1942), using the same method of staining, was particularly successful in the diagnosis of malignant cells in sputum. It is important that the depth of staining should be accurately judged. If the cells are stained too lightly or too deeply the characteristic appearances which are essential for diagnosis will not be clearly shown. In the case of pleural fluid, films are made from the centrifuged deposit and treated in the same way as films of sputum.

For the diagnosis of bronchial carcinoma by examination of the sputum or pleural fluid using the wet film method it is necessary to become familiar with the microscopical appearances of normal and pathological cells of many types. Furthermore, the appearances of cells fixed and stained by this technique differ considerably from those of the same cells seen in paraffin sections. In the wet film method of fixation and staining the cells are not so shrunken and give a more faithful representation of the real morphology. The appearances are more accurate and the detail more intimate. A considerable amount of study is required before one gains a sufficient knowledge to appreciate the pitfalls and the possibilities of this method of examination. In the study of malignant disease of the lung, in addition to the examination of specimens of sputum and pleural fluid, it is essential for purposes of comparison and confirmation to prepare fresh smears from tissues removed at bronchoscopy, from enlarged glands, from secondary nodules of growth, and even from post-mortem material whenever these are available. Paraffin sections should invariably be prepared also. By this procedure it is possible to compare and correlate the findings in the sputum or pleural fluid with those in the actual neoplasm itself. In this way knowledge is built up and gradually extended. It is also necessary to become familiar with the appearances of cells found in sputum and pleural fluid in inflammatory conditions, so that these may be distinguished from malignant cells. In examination of the pleural fluid it is important to recognize and determine the presence of the endothelial cells derived from the pleura, as distinct from clumps of malignant cells which may be present. The different types of cell found in simple purulent sputum are described in detail and well illustrated by Barrett. A good account of the cytology of sputum is also given by Gloyne (1936).

\section{SUMMARY}

The results obtained by examination of sputa and pleural fluids for malignant cells by the wet film method of Dudgeon and Wrigley (1935) at St. Thomas's Hospital, London, are reviewed ; 113 positive results are analysed.

Certain difficulties in the diagnosis of the type of cell present are discussed.

In thirteen cases where the primary growth was extra-thoracic, malignant cells were found in a pleural effusion. In two cases secondary to carcinoma of the breast, the malignant cells in the pleural fluid were found in tiny clumps, surrounded by a layer of endothelial cells. 


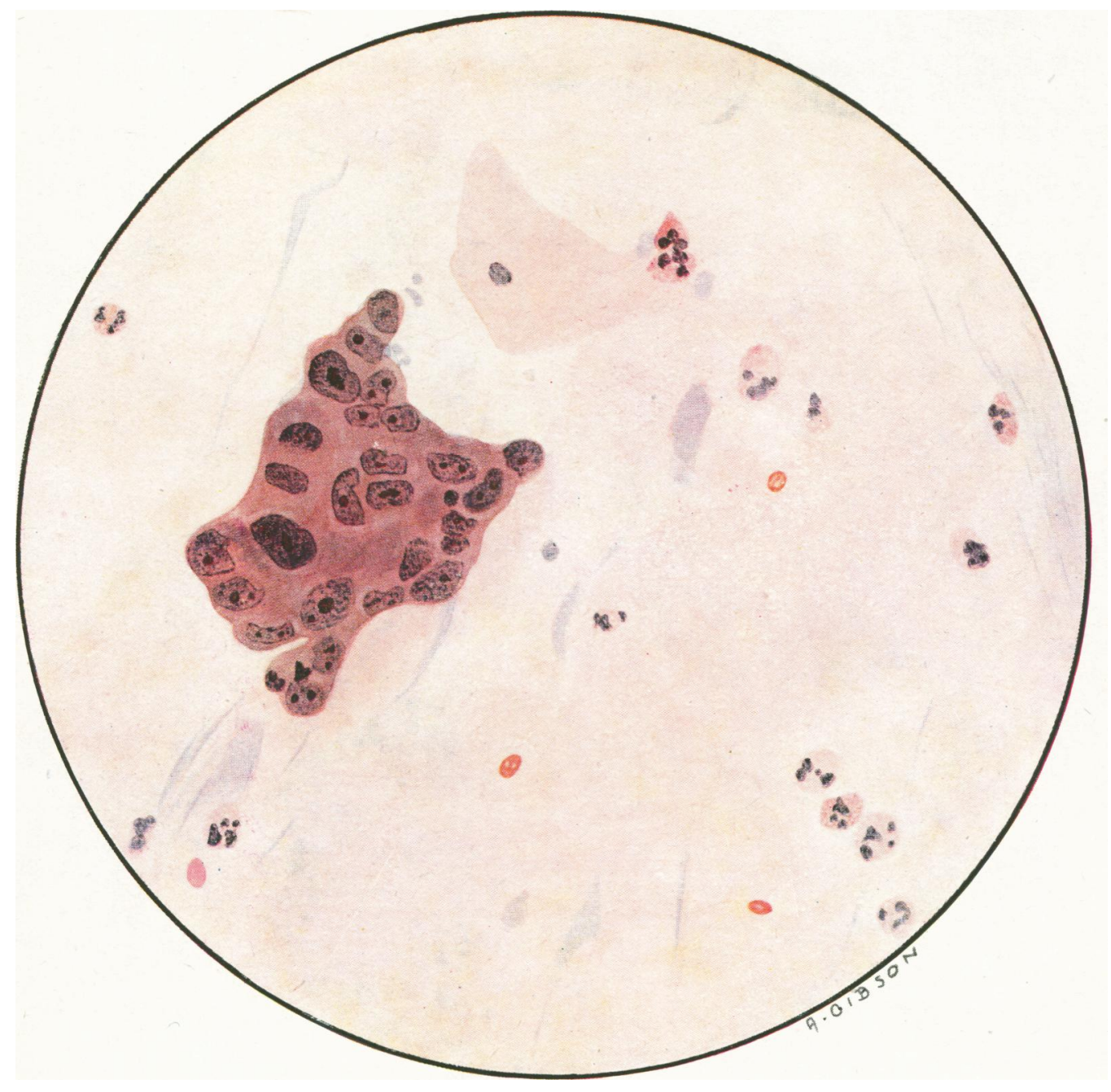

FIG. 4.-A clump of squamous cell carcinoma found in the sputum. Diagnosis confirmed by bronchoscopy and removal of small portion of tissue for histological examination. 


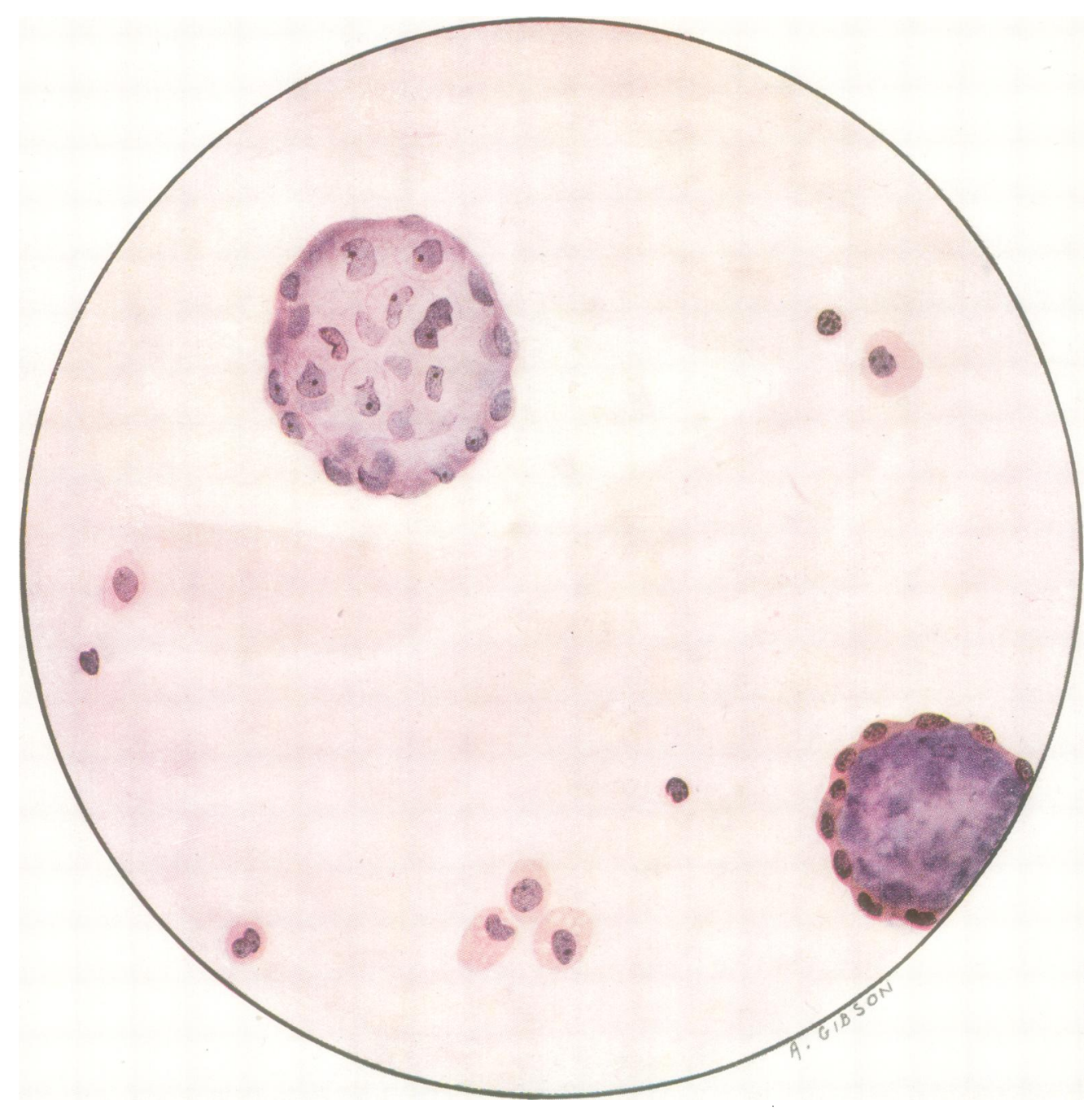

Fig. 5.- Showing tiny spheres of spheroidal cell carcinoma surrounded by a layer of endothelial cells in the pleural fluid. This was secondary to primary spheroidal cell carcinoma of breast removed some years previously. Diagnosis confirmed at autopsy. 
I wish to thank my colleagues, Dr. Anne Gibson and Dr. S. C. Dobson, for their assistance in this work. To Dr. Gibson I am especially indebted for the paintings from which the illustrations were produced.

In addition, I have had the advantage of consultation with Professor Barnard on several occasions, and his help I gratefully acknowledge.

\section{REFERENCES}

Barrett,, N. R. (1938). J. thoracic Surg., 8, 169.

Dudgeon, L. S., and Patrick, C. V. (1927). Brit. J. Surg., 15, 250.

Dudgeon, L. S., and Barrett, N. R. (1934). Brit. J. Surg., 22, 4.

Dudgeon, L. S., and Wrigley, C. H. (1935). J. Laryng. Otol., 50, 752.

Dudgeon, L. S. (1936). St. Thomas's Hosp., Rep., 2s., 1, 51.

Gloyne, S. R. (1936). Tubercle, 18, 292.

Gowar, F. J. S. (1942-3). Brit. J. Surg., 30, 193. 